\title{
Time Value of Money and Happiness
}

\author{
Valor Temporal del Dinero y Felicidad
}

\author{
Alejandro López-Rousseau* \\ Timothy Ketelaar**
}

\begin{abstract}
An important question in the well-being literature is how earning and spending money makes people happy. Some studies have shown that people are happier when earning money in constant payments, and spending money on significant others. However, some
\end{abstract}

findings suggest that people with financial expertise may have different preferences based on the time value of money. The current study was designed to address this issue by asking both financial novices and financial experts if earning money at decreasing, constant or increasing rates would make them happier. By replicating and, more

\section{Author Note}

This research study was approved by the Institutional Review Board of New Mexico State University at Las Cruces, New Mexico, USA. Dr. López-Rousseau conceived and designed the study, analyzed and interpreted the data, and wrote and submitted the manuscript. Dr. Ketelaar sought institutional compliance, collected the data, and revised the draft. We have no conflict of interest to disclose. We thank NMSU students Kendra Summer, Angel Chavez, and DaShawn Robinson for helping in collecting and coding the data. And we also thank the Journal of Psychology editors and anonymous reviewers who evaluated the manuscript.

*Santiago, Chile. Mail de contacto: lopezrousseau@gmail.com

${ }^{* *}$ New Mexico State University. Department of Psychology, DOI: https://doi.org/10.46553/RPSI.17.33.2021.p22-35

Fecha de recepción: 8 de agosto de 2020 - Fecha de aceptación: 27 de noviembre de 2020 
importantly, disambiguating previous findings, the results suggest that financial novices are happier when earning money in constant payments and spending money on debts, whereas financial experts are happier when earning money in decreasing payments and spending money on investments. These findings suggest that earning and spending money makes people happier in different ways depending on their financial expertise. Keywords: well-being, money, happiness, financial expertise

\section{Resumen}

Una cuestión importante en la literatura sobre el bienestar es cómo ganar y gastar dinero hace feliz a la gente. Algunos estudios han demostrado que la gente es más feliz cuando gana dinero en pagos constantes y gasta dinero en personas significativas. Sin embargo, algunos hallazgos sugieren que la gente con experticia financiera puede tener diferentes preferencias basadas en el valor temporal del dinero. El estudio actual fue diseñado para abordar este asunto preguntando tanto a novatos financieros como a expertos financieros si ganar dinero a tasas decrecientes, constantes o crecientes los haría más felices. Al replicar y, más importante todavía, desambiguar hallazgos anteriores, los resultados sugieren que los novatos financieros son más felices cuando ganan dinero en pagos constantes y gastan dinero en deudas, mientras que los expertos financieros son más felices cuando ganan dinero en pagos decrecientes y gastan dinero en inversiones. Estos hallazgos sugieren que ganar y gastar dinero hace que la gente sea más feliz de diferentes maneras dependiendo de su experticia financiera.
Palabras claves: bienestar, dinero, felicidad, experticia financiera

\section{Time Value of Money and Happiness}

For its 30th anniversary, the Association for Psychological Science (APS) invited the authors of the 30 most-cited articles in all its journals over those three decades to revisit these papers in a special publication (Sternberg, 2018a, 2018b). Interestingly enough, six of the articles were on the topic of happiness or well-being, including one specifically on its relationship to money (Diener \& Diener, 1996; Diener \& Seligman, 2002; Diener \& Seligman, 2004; Fredrickson \& Joiner, 2002; Myers \& Diener, 1995; Ryff, 1995). No research topic repeated among the revisited papers, except for happiness (Diener et al., 2018a, 2018b; Fredrickson \& Joiner, 2018; Myers \& Diener, 2018; Ryff, 2018). This fact alone should attest to the relevance and significance of happiness, money, and the relationship between them not just for people but well-being science as well.

A recurring question within the well-being literature is whether, as they say, money buys happiness (e.g., Baucells \& Sarin, 2008; Berk, 2018; Boyce et al., 2017). Empirically, the answer is controversial. According to the Easterlin paradox (Easterlin, 1974, 2010), well-being does vary directly with income both among and within nations at a point in time, but as income continues to grow over time, well-being does not. In the long run, as countries get richer, their citizens do not get happier. In fact, while per capita income has tripled in the past seven decades in the USA, subjective well-being has remained unchanged or 
even declined (Sachs, 2017, 2018). This paradox has been contested by economists (Sacks et al., 2010; Díaz-Castellanos, 2019), psychologists (Diener et al., 2013) and sociologists (Veenhoven \& Vergunst, 2014) who argue that their own analyses show that economic growth does go with greater wellbeing. Then again, Easterlin (2016, 2017) claims that these authors are confusing positive short-term cycles where wealth and happiness expand and contract together with null long-term trends where greater wealth does not go with greater happiness. But be it as it may, Easterlin and his contenders agree that money does buy happiness at least at a point in time.

The question then becomes not whether money buys happiness (D'Ambrosio et al., 2020; Kim \& Oswald, 2020; QuispeTorreblanca et al., 2020) but rather how earning and spending money buys happiness (e.g., Dunn \& Norton, 2013; Lee et al., 2018; Matz et al., 2016). Interestingly enough, people are happier by earning money in constant payments (López-Rousseau \& Cortés, 2010), and by spending money on significant others (Dunn et al., 2008, 2014). Financial expertise, however, apparently changes all of this (López-Rousseau \& Cortés, 2014): When asked to imagine they would win a one million dollars prize payable in five yearly payments, and to choose which of three payment plans -increasing, constant, or decreasing-would make them happier, most financial novices chose constant payments claiming a better distribution of money and/ or management of expenses, and said they would spend the prize on family debts and/ or goods. On the other hand, most financial experts chose decreasing payments claiming a better present value of money and/or future return of investments, and said they would spend the prize on own investments and/or business. In short, while financial novices are happier when earning money in constant payments and spending money on others' debts, financial experts are happier when earning money in decreasing payments and spending money on own investments. That is, regarding earning and spending money to be happy, financial experts apparently prefer a time value of money model where more money sooner is worth more than later because of interest appreciation and/ or inflation depreciation (Drake \& Fabbozi, 2009), rather than an even distribution of money model where present and future worth is not considered (López-Rousseau \& Cortés, 2010, 2014).

However, that research compared younger, non-business major undergraduates to older, business graduate students, thus begging the question of whether the observed differences were due to financial experience - graduate versus undergraduate students - or financial expertise - business versus non-business students. The current study was specifically designed to address this issue by asking both business and non-business graduate students, and nonbusiness major undergraduates, whether earning money at decreasing, constant or increasing rates would make them happier. In this context then, if both business and non-business graduates prefer decreasing payments, and undergraduates do not, it would suggest that their earning preferences are driven by financial experience as opposed to financial expertise. On the contrary, if only business graduates prefer decreasing payments, and both non-business graduates and undergraduates do not, it would suggest 
that their earning preferences are driven by financial expertise as opposed to financial experience.

\section{Method}

\section{Sample}

The current study replicated López-Rousseau \& Cortés' (2014) methodology using a new sample of 84 students from New Mexico State University at Las Cruces, USA (56 women and 28 men, Mage $=24,5$ years, range: 20 47 years), who were properly treated and credited for their participation. Like in that study, some participants had both financial experience and financial expertise Master of Business Administration graduate students or, simply, MBAs), and some had neither (31 Bachelor of Arts undergraduates in Psychology or BAs). Unlike in that study, some participants had financial experience but not financial expertise (30 Master of Arts graduate students in Anthropology or MAs).

\section{Instrument}

A printed questionnaire with instructions and items was prepared that read as follows:

The purpose of this questionnaire is to explore the relationship between money and happiness. To this end, briefly answer the three following questions, please. Thanks. Imagine you would win a 1 million dollars prize payable in five yearly payments.

1. What payment plan would make you happier? Please answer by checking plan A, $\mathrm{B}$ or $\mathrm{C}$ in the table below, which shows the yearly payments in thousands of dollars that you would be paid in each case:
2. Why? Please answer below:

3. What would you spend the money on?

Please answer below:

\section{Design}

The questionnaire was presented to participants in class. Each student took about ten minutes to complete the survey. More specifically, participants were asked to imagine they would win a one million dollars prize payable in five yearly payments, and to choose which of three payment plans decreasing, constant, or increasing- would make them happier. They were also asked for the reason of their paymet plan preference, and for the matter of their prize money spending. After the participants answered the questionnaire, they were properly debriefed about the study.

Figure 1 illustrates the payment amount by payment year and payment plan. The decreasing payment plan would pay participants $300,250,200,150$, and 100 thousand dollars the first, second, third, fourth, and fifth year, repectively. The constant plan would pay them 200 thousand dollars each of the five years. And the increasing plan would pay participants 100 , 150, 200, 250, and 300 thousand dollars each respective year. The three payment plans decreasing, constant, and increasing- were presented in a table, and labelled A, B and $\mathrm{C}$ from first to last to avoid possible positive or negative semantic effects. The order of the three plans was counterbalanced across participants to avoid possible primacy or recency effects as well.

To test whether people are happier

\begin{tabular}{lllllll} 
Plan & Year 1 & Year 2 & Year 3 & Year 4 & Year 5 & Total \\
\hline Plan A & 100 & 150 & 200 & 250 & 300 & 1,000 \\
Plan B & 200 & 200 & 200 & 200 & 200 & 1,000 \\
Plan C & 300 & 250 & 200 & 150 & 100 & 1,000 \\
\hline
\end{tabular}




\section{Figure 1}

Payment Amount by Payment Year and Payment Plan

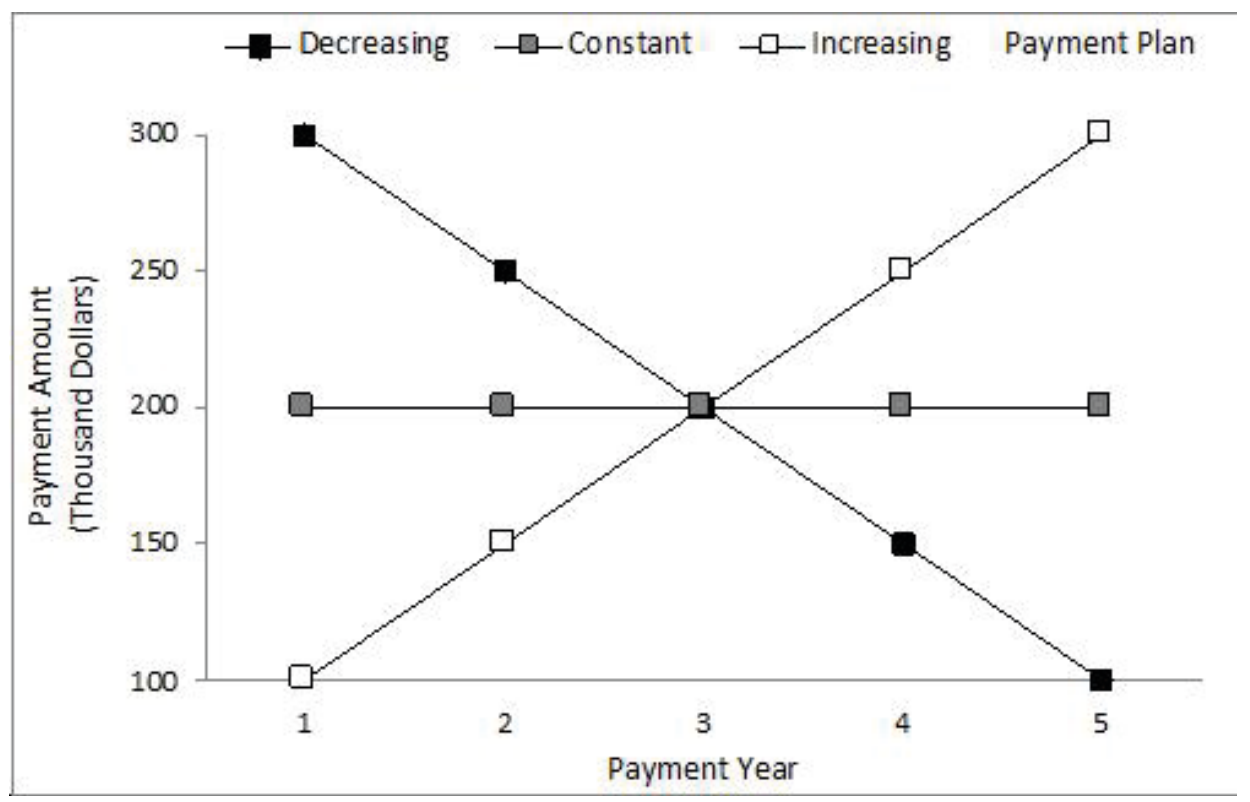

by earning money in decreasing payments because of financial experience or financial expertise, it was assumed that student age is a proxy for general financial experience, and study program is a proxy for specific financial expertise. That is, it was expected that older students (MAs \& MBAs) would have more experience in financial practices (e.g., mortgage payment) than younger students (BAs), and that business students (MBAs) would have more expertise in financial principles (e.g., time value of money) than non-business students (BAs and MAs). Thus, preferring decreasing payments would be a matter of financial experience if both experienced MBAs and MAs alike preferred decreasing payments, and non-experienced BAs did not. But preferring decreasing payments would be a matter of financial expertise if only expert MBAs preferred decreasing payments, and both non-expert MAs and BAs did not.

\section{Results}

Age Differences

Figure 2 shows the mean age of participant students by study program. As expected, BAs (Mage $=21,7$ years, range: $20-32$ ) were significantly younger than both MAs (Mage $=25,7$ years, range: 22-32) and MBAs (Mage $=26,9$ years, range: $21-47$ ) who were both equally old, as tested by an analisys of variance, $F(2,80)=12.50, p<.001$, and 


\section{Figure 2}

Mean Age of Participant Students by Study Program

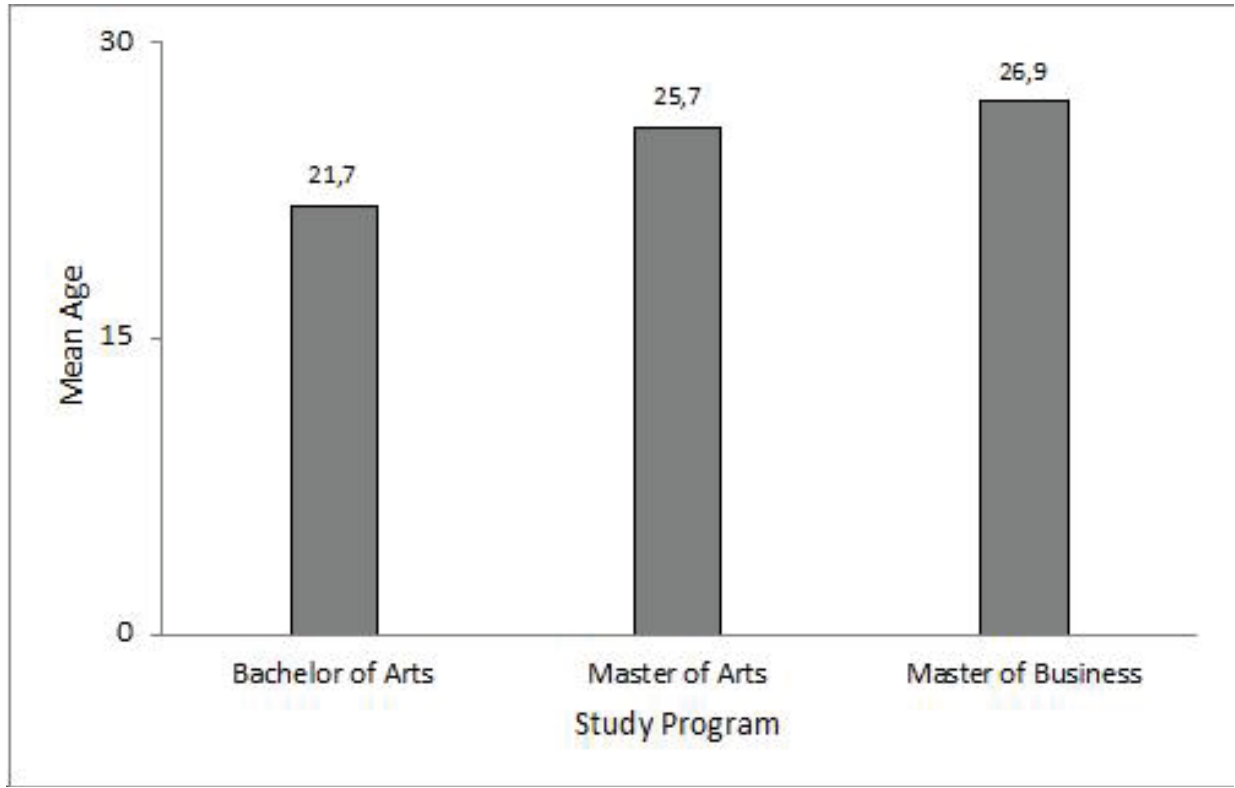

respective planned comparisons, $t(80)=$ $4.49, p<.001 ; t(80)=-1.12, p=.268$. These findings are consistent with the relativeage-based assumption that undergraduates students (BAs) would be less experienced financially than graduate students (MAs \& MBAs), and that graduate students (MAs \& MBAs) would be equally experienced financially regardless of study program.

\section{Did Experienced Students Prefer Decreasing Payments Depending on Their Relative Financial Expertise?}

Figure 3 shows the choice percentage of payment plan by study program. Whereas most MBAs (52\%) chose decreasing payments, both most MAs (80\%) and BAs
$(65 \%)$ chose constant payments, $\chi^{2}(4,84)=$ $27.53, p<0.001$. In fact, $82 \%$ of participants' responses matched financial-expertise expectations -expert MBAs choosing decreasing payments plus non-expert MAs and BAs choosing otherwise- which is a strong person-centered effect size (Grice et al., 2020). This suggests that preferring decreasing payments is not a matter of financial experience but financial expertise, because only expert MBAs preferred decreasing payments, and both non-expert MAs and BAs did not. That is, financially experienced experts (MBAs) chose decreasing payments, whereas experienced non-experts (MAs) chose constant payments just like non-experienced non-experts 
Figure 3

Choice Percentage of Payment Plan by Study Program

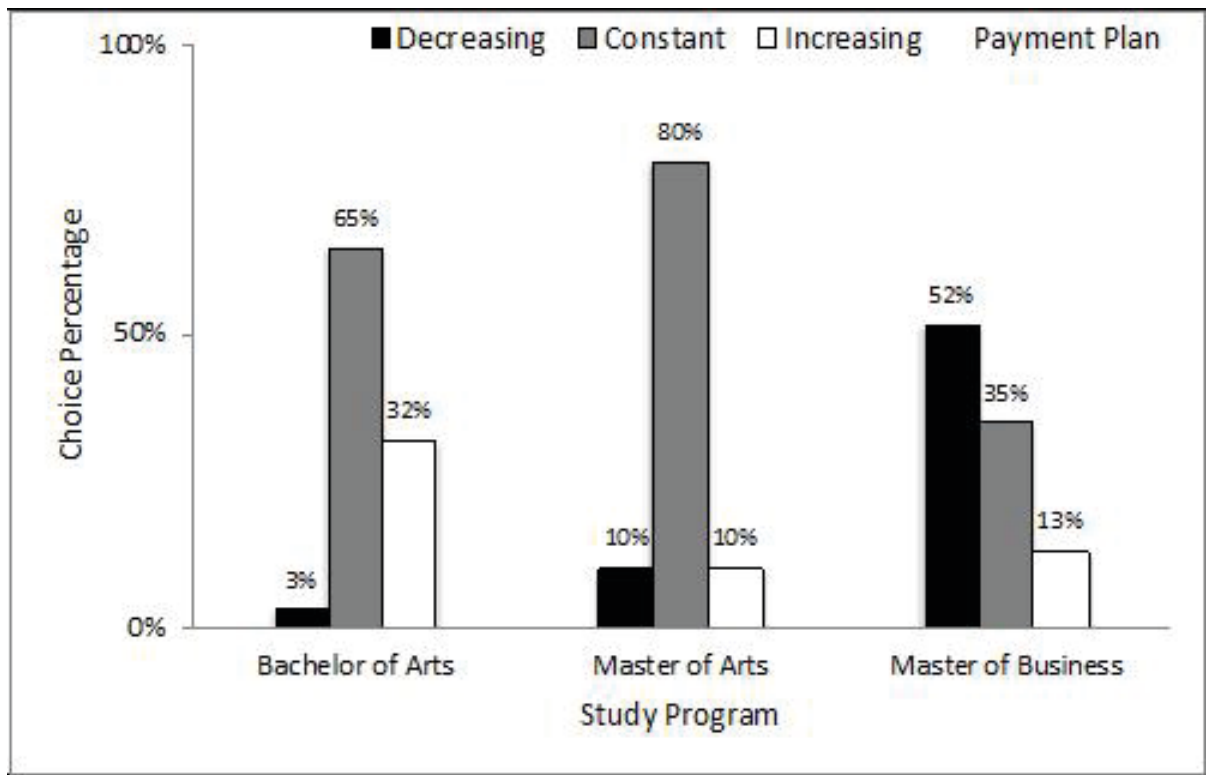

(BAs). Together, these findings suggest that financial experts are happier by earning money in decreasing payments, whereas financial novices are happier by earning money in constant payments, regardless of financial experience.

\section{Why Did Experienced Students Prefer Decreasing Payments Depending on Their Relative Financial Expertise?}

Figure 4 shows the choice percentage of payment plan preference reason by study program. Whereas most MBAs (83\%) who chose decreasing payments justified it by a better present value of money and/or future return of investments (e.g., a dollar today is worth more than a dollar tomorrow), most MAs (96\%) who chose constant payments justified it by a better distribution of money and/or management of expenses (e.g., evenly spaced and easier to budget for future goals), $\chi^{2}(2,36)=49.54, p<0.001$. In fact, $94 \%$ of participants' responses matched financialexpertise expectations - expert MBAs choosing better present value of money and/ or future return of investments plus nonexpert MAs choosing otherwise - which is a very strong person-centered effect size. That is, whereas experienced experts (MBAs) chose decreasing payments because of money's changing value in time, experienced non-experts (MAs) chose constant payments 
Figure 4

Choice Percentage of Payment Plan Preference Reason by Study Program

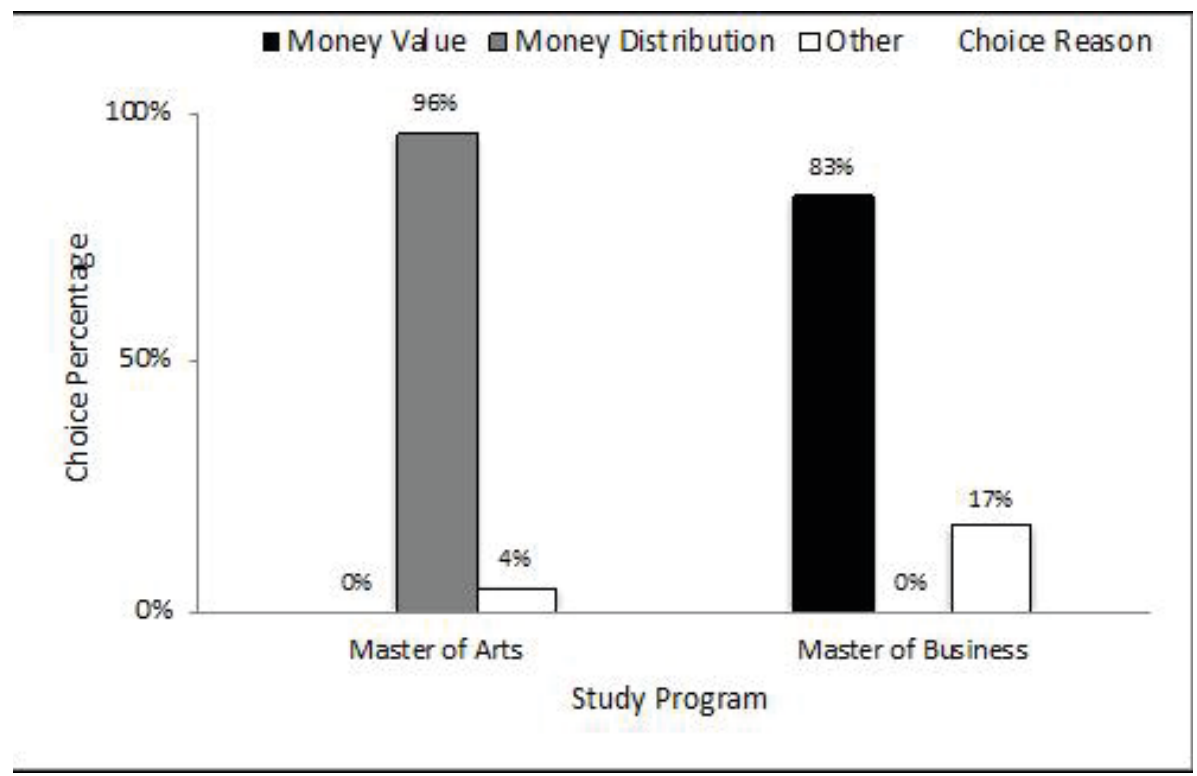

because of money's unchanged distribution in time. Together, these findings suggest that financial experts are happier by earning money in decreasing payments based on a principled time value of money model, whereas financial novices are happier by earning money in constant payments based on a practical even distribution of money model.

\section{Would Experienced Students Spend Money Differently Depending on Their Relative Financial Expertise?}

Figure 5 shows the choice percentage of prize money spending matter by study program. Given their unique first answer, whereas most MBAs (58\%) who chose decreasing payments would spend the prize on investments and/or business (e.g., investments in business ventures), most MAs (75\%) who chose constant payments would spend the prize on debts and/or goods (e.g., pay off student loans), $\chi^{2}(2,36)=13.36, p=$ 0.001 . In fact, $69 \%$ of participants' responses matched financial-expertise expectations expert MBAs choosing investments and/ or business plus non-expert MAs choosing otherwise- which is a fairly strong effect size. That is, whereas experienced experts (MBAs) would invest the money, experienced non-experts (MAs) would repay their debts. Together, these findings suggest 


\section{Figure 5}

\section{Choice Percentage of Prize Money Spending Matter by Study Program}

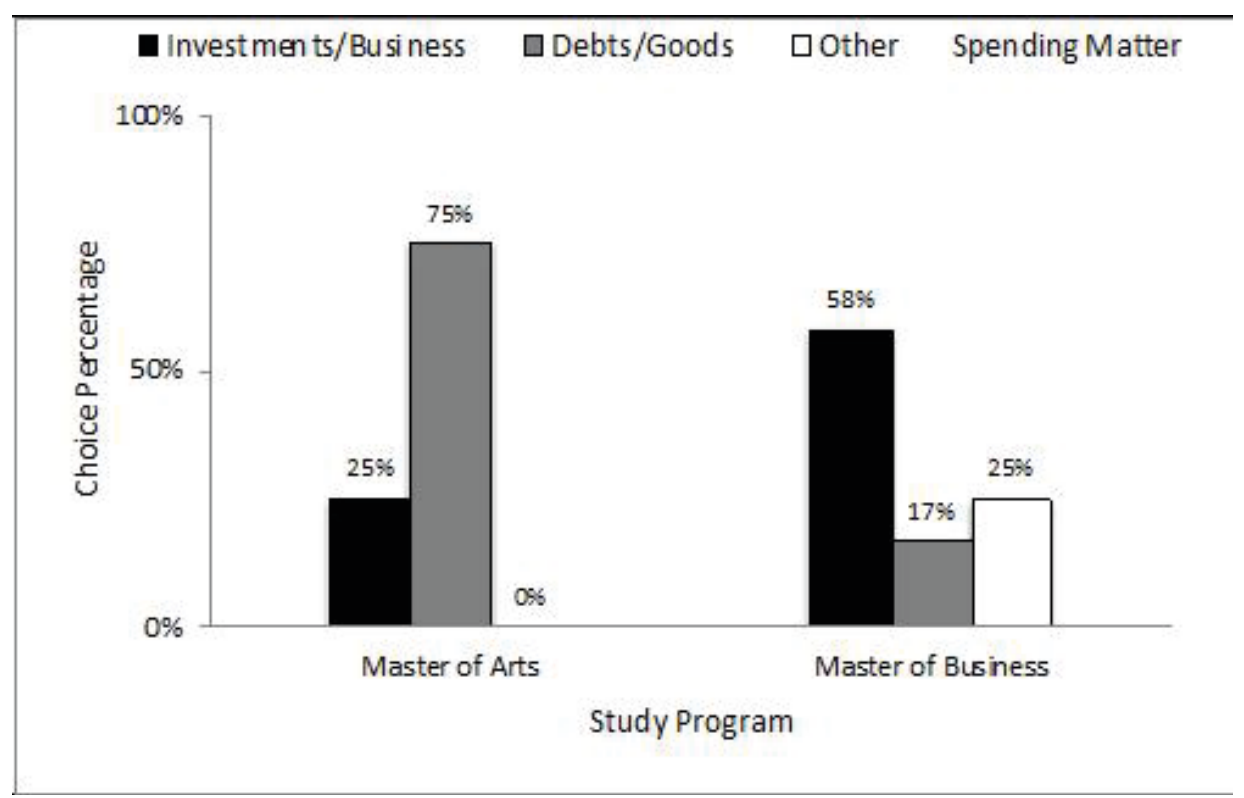

that financial experts are happier by spending money based on future returns, whereas financial novices are happier by spending money based on present needs.

\section{Discussion}

The present study closes a circle regarding the question of how earning and spending money makes people happy. According to economist Easterlin (1974, 2010, 2016, 2017), money makes people happy but only up to a point where paradoxically it does not anymore. According to other economists (Sacks et al., 2010; Díaz-Castellanos, 2019) and psychologists or sociologists (Diener et al., 2013; Veenhoven \& Vergunst, 2014), money keeps making people happy beyond that point. However, they all agree that money makes people happy at least up to a point. The question thus becomes not whether but how exactly does money make people happy.

According to a prescriptive economic model (Baucells \& Sarin, 2008), the answer simply is increasing rates. That is, money should make people happier if earned and spent at increasing rates because so the expected utility of expanding consumption would be fully maximized. Or in other words, increasing rates of money would yield increasing rates of happiness. However, for a prescriptive financial model (Drake \& Fabbozi, 2009), the answer simply is 
decreasing rates. That is, money should make people happier if earned and spent at decreasing rates because so the expected utility of expanding investment would be fully maximized. Or in other words, decreasing rates of money would yield increasing rates of happiness.

López-Rousseau and Cortés (2010, 2014) empirically tested both these prescriptive models, and found that money makes most people happier not by increasing nor decreasing but constant rates of earning and spending. This descriptive psychological model shows that money makes people happier if earned and spent at constant rates because so the expected utility of constant income and expense is fully maximized. Or in other words, constant rates of money yield increasing rates of happiness. In fact, most people think money buys happiness in constant payments because of better income distributiuon and better expense management on debts and goods. Nonetheless, they also found that decreasing rates of earning and spending money does make some people happier, namely, financial experts. Experts think money buys happiness in decreasing payments because of better present value of money and future return of investments and business. But whether it was financial expertise or experience that accounted for some people's preferences for decreasing rates as opposed to most people's preferences for constant rates remained an open question. The results presented here clearly answer that question by showing that it is actually financial expertise not experience that makes the difference. That is, regardless of financial experience, financial novices
- most people — are happier by earning money in constant payments based on an even distribution of money model, and by spending money on debts based on present needs. On the contrary, financial experts - some people - are happier by earning money in decreasing payments based on a time value of money model, and by spending money on investments based on future returns. These findings replicate and, more importantly, disambiguate López-Rousseau and Cortés' findings (2010, 2014) closing thus the circle regarding the question of how earning and spending money makes people happy.

In conclusion, as Easterlin (2016) himself proposed, it is time to move on beyond the apparent paradox of whether money buys happiness or not to other facts, such as how earning and spending money buys happiness. In this light, the current study might be a step in the right direction by showing that earning and spending money makes people happier in different ways depending on their financial expertise. That is, decreasing rates of earning and spending money make some people - financial experts - actually happier based on economically optimal rational principles such as time value of money. On the other hand, constant rates of earning and spending money make most people -financial novices - actually happier based on ecologically adaptive satisficing heuristics (Gigerenzer, 2019) such as even distribution of money. Given real worlds of monthly income (e.g., salary) and expense (e.g., mortgage), people's money-happiness constant rates heuristic actually fits perfectly well: it is ecologically rational. 


\section{References}

Baucells, M., \& Sarin, R. K. (2008). Doesmore money buy you more happiness? In T. Kugler, J. C. Smith, T. Connolly, \& Y. J. Son (Eds.), Decision modeling and behavior in complex and uncertain environments (pp. 199-226). Springer. https://doi. org/10.1007/978-0-387-77131-1 9

Berk, K. (2018). Does money make us happy? The prospects and problems of happiness research in economics. Journal of Happiness Studies, 19(4), 1241-1245. https://doi. org/10.1007/s10902-017-9857-y

Boyce, C. J., Daly, M., Hounkpatin, H. O., \& Wood, A. M. (2017). Money may buy happiness, but often so little that it doesn't matter. Psychological Science, 28(4), 544-546. https://doi. org $/ 10.1177 / 0956797616672271$

D’Ambrosio C., Jäntti, M., \& Lepinteur, A. (2020). Money and happiness: Income, wealth and subjective wellbeing. Social Indicators Research, 148(1), 47-66. https://doi. org/10.1007/s11205-019-02186-W

Díaz-Castellanos, G. (2019). Más ingreso, más felicidad. ¿Hasta cuánto? Revista Académica Eco, 20, 39-50. http://168.234.75.179/index.php/ race/article/download/1060/938

Diener, E., \& Diener, C. (1996). Most people are happy. Psychological Science, 7(3), 181-185. https:// doi.org/10.1111/j.1467-9280.1996. tb00354.x

Diener, E., Diener, C., Choi, H., \& Oishi, S. (2018a). Revisiting "Most people are happy"-and discovering when they are not. Perspectives on Psychological Science, 13(2), 166-170. https://doi. org/10.1177/1745691618765111

Diener, E., \& Seligman, M. E. P. (2002). Very happy people. Psychological Science, 13(1), 81-84. https://doi. org/10.1111/1467-9280.00415

Diener, E., \& Seligman, M. E. P. (2004). Beyond money: Toward an economy of well-being. Psychological Science in the Public Interest, 5(1), 1-31. https://doi.org/10.1111/ j.0963-7214.2004.00501001.x

Diener, E., \& Seligman, M. E. P. (2018). Beyond money: Progress on an economy of well-being. Perspectives on Psychological Science, 13(2), 171-175. https://doi. org/10.1177/1745691616689467

Diener, E., Seligman, M. E. P., Choi, H., \& Oishi, S. (2018b). Happiest people revisited. Perspectives on Psychological Science, 13(2), 176-184. https://doi. org $10.1177 / 1745691617697077$

Diener, E., Tay, L., \& Oishi, S. (2013). Rising income and the subjective well-being of nations. Journal of Personality and Social Psychology, 104(2), 267-276. https://doi. org/10.1037/a0030487

Drake, P.P. and Fabozzi, F.J. (2009) Foundations and Applications of the Time Value of Money. Wiley. https:// doi.org/10.1002/9781118267868

Dunn, E. W., Aknin, L. B., \& Norton, M. I. (2008). Spending money on others promotes happiness. Science, 
319(5870), 1687-1688. https://doi. org/10.1126/science.1150952

Dunn, E. W., \& Norton, M. (2013). Happy Money: The Science of Smarter Spending. Simon \& Schuster. https://www.simonandschuster. com/books/Happy-Money/ Elizabeth-Dunn/9781451665079

Dunn, E. W., Aknin, L. B., \& Norton, M. I. (2014). Prosocial spending and happiness: Using money to benefit others pays off. Current Directions in Psychological Science, 23(1), 41-47. https://doi. org $/ 10.1177 / 0963721413512503$

Easterlin, R. A. (1974). Does economic growth improve the human lot? Some empircal evidence. In P. A. David \& M. W. Reder (Eds.), Nations and Households in Economic Growth: Essays in Honour of Moses Abramovitz (pp. 89-125). Academic Press. https:// doi.org/10.1016/B978-0-12205050-3.50008-7

Easterlin, R. A., McVey, L. A., Switek, M., Sawangfa, O., \& Zweig, J. S. (2010). The happiness-income paradox revisited. Proceedings of the National Academy of Sciences, 107(52), 22463-22468. https://doi. org/10.1073/pnas. 1015962107

Easterlin, R. A. (2016). Paradox Lost? (Research Paper No. 16-02). USC Institute for New Economic Thinking. $\quad$ https://dx.doi. org $/ 10.2139 /$ ssrn.2714062

Easterlin, R. A. (2017) Economic growth increases people's wellbeing. In B. Frey \& D. Iselin (Eds.), Economic Ideas You Should
Forget (pp. 37-38). Springer. https://doi.org/10.1007/978-3-31947458-8 15

Fredrickson, B. L., \& Joiner, T. (2002). Positive emotions trigger upward spirals towards emotional wellbeing. Psychological Science, 13(2), 172-175. https://doi. org/10.1111/1467-9280.00431

Fredrickson, B. L., \& Joiner, T. (2018). Reflections on positive emotions and upward spirals. Perspectives on Psychological Science, 13(2), 194-199. https://doi. org/10.1177/1745691617692106

Gigerenzer, G. (2019). Axiomatic rationality and ecological rationality. Synthese. Advance online publication. https:// doi.org/10.1007/s11229-019$\underline{\text { 02296-5 }}$

Grice, J. W., Medellin, E., Jones, I., Horvath, S., McDaniels, H., O'Iansen, C., \& Baker, M. (2020). Persons as effect sizes. Advances in Methods and Practices in Psychological Science. Advance online publication. https://doi. org $/ 10.1177 / 2515245920922982$

Kim, S., \& Oswald, A. J. (2020). Happy lottery winners and LT bias. Review of Income and Wealth. Advance online publication. https://doi. org/10.1111/roiw.12469

Lee, J. C., Hall, D. L., \& Wood, W. (2018). Experiential or material purchases? Social class determines purchase happiness. Psychological Science, 29(7), 1031-1039. https://doi. org/10.1177/0956797617736386

López-Rousseau, A., \& Cortés, C. (2010). Money buys happiness in constant 
payments. Revista de Psicología, 6(12), 57-63. https://repositorio. uca.edu.ar/handle/123456789/6153

López-Rousseau, A., \& Cortés, C. (2014). Slumdog Millionaire: Money and happiness beyond movies. International Journal of Happiness and Development, 1(4), 384 392. https://doi.org/10.1504/ IJHD. 2014.066134

Matz, S. C., Gladstone, J. J., \& Stillwell, D. (2016). Money buys happiness when spending fits our personality. Psychological Science, 27(5), 715-725. https://doi. org $/ 10.1177 / 0956797616635200$

Myers, D. G., \& Diener, E. (1995). Who is happy? Psychological Science, 6(1), 10-19. https://doi. org/10.1111/j.1467-9280.1995. tb00298.x

Myers, D. G., \& Diener, E. (2018). The scientific pursuit of happiness. Perspectives on Psychological Science, 13(2), 218-225. https://doi. org/10.1177/1745691618765171

Quispe-Torreblanca, E. G., Brown, G. D. A., Boyce, C. J., Wood, A. M., \& De Neve, J-E. (2020). Inequality and social rank: Income increases buy more life satisfaction in more equal countries. Personality and Social Psychology Bulletin. Advance online publication. https://doi. org/10.1177/0146167220923853

Ryff, C. D. (1995). Psychological well-being in adult life. Current Directions in Psychological Science, 4(4), 99104. https://doi.org/10.1111/1467$\underline{8721 . e p 10772395}$

Ryff, C. D. (2018). Well-being with soul: Science in pursuit of human potential. Perspectives on Psychological Science, 13(2), 242-248. https://doi. org/10.1177/1745691617699836

Sachs, J. D. (2017). Restoring American happiness. In J. Helliwell, R. Layard, \& J. Sachs (Eds.), World Happiness Report 2017 (pp. 178184). Sustainable Development Solutions Network. https:// s3.amazonaws.com/happinessreport/2017/HR17-Ch7.pdf

Sachs, J. D. (2018). America's health crisis and the Easterlin paradox. In J. Helliwell, R. Layard, \& J. Sachs (Eds.), World Happiness Report 2018 (pp. 146-159). Sustainable Development Solutions Network. https://s3.amazonaws.com/ happiness-report/2018/CH7-WHRlr.pdf

Sacks, D. W., Stevenson, B., \& Wolfers, J. (2010). Subjective well- being, income, economic development, and growth (Working Paper 16441). National Bureau of Economic Research. https://doi.org/10.3386/ $\underline{w 16441}$

Sternberg, R. J. (2018a). Which articles make a difference? Introduction to the special 30th APS anniversary issue of Perspectives on Psychological Science. Perspectives on Psychological Science, 13(2), 127-129. https://doi. org/10.1177/1745691617708632

Sternberg, R. J. (2018b). The scientific work we love: A duplex theory of scientific impact and its application to the top-cited articles in the 
first 30 years of APS journals. Perspectives on Psychological Science, 13(2), 260-267. https://doi. org/10.1177/1745691617752690

Veenhoven, R., \& Vergunst, F. (2014). The Easterlin illusion: economic growth does go with greater happiness. International Journal of Happiness and Development, 1(4), 311-343. https://doi.org/10.1504/ IJHD.2014.066115 